\title{
Beet production using vermiculite incorporated with Dystrophic Red Latosol (Oxisol)
}

\author{
Produção de beterraba utilizando vermiculita incorporada em Latossolo Vermellho Distrófico \\ Producción de remolacha usando vermiculita incorporada en Latosol Rojo Distrófico
}

Received: 12/13/2020 | Reviewed: 12/20/2020 | Accept: 01/11/2021 | Published: 01/13/2021

\author{
Ariel Santivañez Aguilar \\ ORCID: https://orcid.org/0000-0003-2743-9147 \\ São Paulo State University. Brazil \\ E-mail: ariel.santivanez@unesp.br \\ Henrique Vasque \\ ORCID: https://orcid.org/0000-0002-7023-0501 \\ São Paulo State University. Brazil \\ E-mail: henriquevasq@gmail.com \\ Antonio Ismael Inácio Cardoso \\ ORCID: https://orcid.org/0000-0003-3251-9491 \\ São Paulo State University. Brazil \\ E-mail: antonio-ismael.cardoso@unesp.br \\ Estefânia Martins Bardiviesso \\ ORCID: https://orcid.org/0000-0001-7331-9491 \\ São Paulo State University. Brazil \\ E-mail: estefania.bardiviesso@hotmail.com \\ Raíra Andrade Pelvine \\ ORCID: https://orcid.org/0000-0001-9005-6128 \\ São Paulo State University. Brazil \\ E-mail: raira_andpelvine@hotmail.com \\ Sara Raissa Brito Bezerra \\ ORCID: https://orcid.org/0000-0003-0540-7160 \\ São Paulo State University. Brazil \\ E-mail: sararaissabezerra@gmail.com \\ Maurício Dominguez Nasser \\ ORCID: https://orcid.org/0000-0002-4239-5958 \\ São Paulo Agribusiness Technology Agency. Brazil \\ E-mail: mdnasser@apta.sp.gov.br \\ Fernando Ferrari Putti \\ ORCID: https://orcid.org/0000-0002-0555-9271 \\ São Paulo State University. Brazil \\ E-mail: fernando.putti@unesp.br \\ Ernane Miranda Lemes \\ ORCID: https://orcid.org/0000-0001-6807-0644 \\ Federal University of Uberlândia. Brazil \\ E-mail: ernanefito@gmail.com
}

\begin{abstract}
Vermiculite is an expansive material that can be used for crop production. However, information about the use of vermiculite in vegetable production is scarce. Thus, this study's objective was to evaluate the effects of vermiculite levels incorporated into the soil (Red Latosol Dystrophic) for beet (Beta vulgaris L.) crop production. The experiment

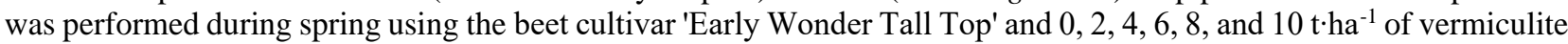
incorporated into the soil before seedling planting. The increase of the vermiculite doses caused a linear decrease of the fresh root and leaf weight. The yield reductions were due to the great water holding capacity of the vermiculite and the consequent high incidence of cercosporiosis (Cercospora beticola Saac).
\end{abstract}

Keywords: Beta vulgaris L.; Hydrated silicate; Cercosporiosis; Plant development; Crop yield.

\section{Resumo}

Vermiculita é um material expansivo que pode ser usado para a produção de culturas agrícolas. No entanto, as informações sobre o uso da vermiculita na produção de hortícolas são escassas. Assim, o objetivo deste estudo foi avaliar os efeitos dos níveis de vermiculita incorporados no solo (Latossolo Vermelho Distrófico) para a produção de beterraba (Beta vulgaris L.). O experimento foi realizado durante a primavera usando a cultivar de beterraba 'Early Wonder Tall Top' e 0, 2, 4, 6, 8 e 10 th ha $\mathrm{a}^{-1}$ de vermiculita incorporada ao solo antes do plantio das mudas. $\mathrm{O}$ aumento das doses de vermiculita causou uma diminuição linear da biomassa de raiz fresca e folhas da beterraba. As reduções do rendimento se devem à grande capacidade de retenção de água do vermiculita e à consequente alta incidência de cercosporiose (Cercospora beticola Saac).

Palavras-chave: Beta vulgaris L.; Silica hidratada; Cercosporiose; Desenvolvimento de planta; Produção agrícola. 


\section{Resumen}

La vermiculita es un material expansivo que se puede utilizar para la producción de cultivos. Sin embargo, la información sobre el uso de vermiculita en la producción de vegetales es escasa. El objetivo de este estudio ha sido evaluar los efectos de los niveles de vermiculita incorporados en el suelo (Latosol Rojo Distrófico) para la producción de cultivos de remolacha (Beta vulgaris L.). El experimento se ha realizado durante la primavera utilizando el cultivar "Early Wonder Tall Top" con dosis de: 0, 2, 4, 6, 8 y 10 t ha $^{-1}$ de vermiculita incorporado al suelo antes del transplante. El aumento de las dosis de vermiculita ha causado una disminución lineal del peso fresco de la raíz y la hoja. Las reducciones del rendimiento se ha debido a la gran capacidad de retención de agua de la vermiculita y por consiguiente a una alta incidencia de cercosporiosis (Cercospora beticola Saac).

Palabras-clave: Beta vulgaris L.; Sílica hidratada; Cercosporiosis; Desarrollo vegetal; Producción agrícola.

\section{Introduction}

Beet (Beta vulgaris L.) is a plant species belonging to the Quenopodiacea family, originally from European and North African temperate regions, but today is grown in all continents. The edible part of the plant is a globular-shaped, usually a reddish-colored tuberous root rich in vitamins and minerals. This crop can be directly sown (seeds) or planted (seedlings) with bare root or germinated on trays with the substrate (Filgueira, 2012). For table beet production is usually necessary clay soils, with the large availability of mineral nutrients and high organic matter content (Sediyama et al., 2011; Xavier et al., 2013).

Vermiculite is a hydrated silicate mineral, containing varying amounts of iron, magnesium, potassium, and aluminum (Castro et al., 2011; Gooch, 2011), which can be used in adsorption of heavy metals due to its surface characteristics (Chui, 2005; França et al., 2006). The main applications of vermiculite in agriculture are as a substrate for plants (Curbelo, 2002), and as a seed germinator for many plant species (Vidigal et al., 2007; Araújo et al., 2020; Ferraz et al., 2020). In Brazil, the use of vermiculite in agriculture is still limited, and the suppliers are restricted to companies in the industrial and construction sectors (Ugarte et al., 2005).

Vermiculite is a viable alternative to support the in vitro propagation of sweet potatoes (Orellana, 2016), and its use has produced beet seedlings of higher quality than in coconut fiber (Oliveira, 2012). The main disadvantage is that vermiculite compresses easily, being able to collapse and lose its structure, an undesirable situation for long cycle crops but not for seedlings production (Villegas, 2017) or short-cycle crops.

Vermiculite is also non-phytotoxic, chemically, and texturally uniform in composition, with high water retention capacity, good aeration due to its physicochemical properties, ultra-lightweight, and is easily obtained (Figliolia et al., 1993; Vidigal et al., 2007). Due to those characteristics, vermiculite uses has been increasing (Silva et al., 2015). Thus, the objective of the work was to evaluate the effects of levels of vermiculite incorporated in the soil for beet production.

\section{Methodology}

The experiment was implemented at the São Paulo State University (UNESP), Botucatu campus, São Manuel, São Paulo state, Brazil, at $22^{\circ} 46^{\prime} \mathrm{S}$ and $48^{\circ} 34^{\prime} \mathrm{W}$ and $740 \mathrm{~m}$ above sea level. The prevailing climate is Cfa type (subtropical humid Köppen's classification), with the average temperature of the hottest month superior to $22{ }^{\circ} \mathrm{C}$, and $1,377 \mathrm{~mm}$ of average annual rainfall (Cunha and Martins, 2009). The experimental area and crop management were selected to represent an adequate crop condition for beet production.

The soil of the experimental area is classified as a Dystrophic Red Latosol (Oxisol). At 0-0.2 m soil depth the soil chemical analysis indicated: soil $\mathrm{pH}=5.6$; organic matter content $=19 \mathrm{~g} \cdot \mathrm{dm}^{-3} ; \mathrm{P}=98 \mathrm{mg} \cdot \mathrm{dm}^{-3} ; \mathrm{H}^{+}+\mathrm{Al}^{3+}=12 \mathrm{mmol}_{\mathrm{c}} \cdot \mathrm{dm}^{-3} ; \mathrm{K}^{+}=$ $1.9 \mathrm{mmol}_{\mathrm{c}} \cdot \mathrm{dm}^{-3} ; \mathrm{Ca}^{2+}=37 \mathrm{mmol}_{\mathrm{c}} \cdot \mathrm{dm}^{-3} ; \mathrm{Mg}^{2+}=13 \mathrm{mmol}_{\mathrm{c}} \cdot \mathrm{dm}^{-3}$; soil base sum $=52 \mathrm{mmol}_{\mathrm{c}} \cdot \mathrm{dm}^{-3} ;$ cation exchange capacity $(\mathrm{CEC})$ $=64 \mathrm{mmol}_{\mathrm{c}} \cdot \mathrm{dm}^{-3}$, and soil base saturation $=81 \%$.

The beet cultivar studied was "Early Wonder Tall Top". The beet seeds were sown in polypropylene trays (288 cells) containing commercial substrate and only one seed per cell. The initial soil fertilization included 20,180 and $120 \mathrm{~kg} \cdot \mathrm{ha} \mathrm{a}^{-1} \mathrm{of} \mathrm{N}$, 
$\mathrm{P}_{2} \mathrm{O}_{5}$ and $\mathrm{K}_{2} \mathrm{O}$, respectively. The fertilization of the soil of the experimental area also included $90 \mathrm{~kg} \cdot \mathrm{ha}^{-1}$ of $\mathrm{N}$ as urea and 45 $\mathrm{kg} \cdot \mathrm{ha}^{-1}$ of potassium chloride ( $\mathrm{KCl}$ ) divided into three (3) applications, at 14, 28 and 42 days after transplanting (DAT) for all treatments. All fertilizations were done according to the recommendations of Raij et al. (1997) for beet production.

The soil preparation followed the recommendation by Filgueira (2012). The seedling transplanting to the field (October) happened 35 days after sowing (September). The soil beds where the beet seedlings were planted presented four (4) planting lines spaced by $0.25 \mathrm{~m}$ and the plants in line were spaced by $0.1 \mathrm{~m}$.

The experimental design was also planned to represent an adequate condition to respond to questions about the viability of the use of vermiculite as a substrate component for beet production (Pereira et al., 2018); thus, the experiment was set as a randomized block design with 5 replications and the treatments were $0,2,4,6,8$, and 10 tha $^{-1}$ of vermiculite. The vermiculite was incorporated manually to reach a homogeneous distribution 15 days before the seedling transplant. The area of each experimental plot (soil bed) was $1 \times 1 \mathrm{~m}^{2}$. Plants were irrigated with sprinklers and water was supplied up to maintain $60 \%$ of field capacity. Copper-based products were used to control cercosporiosis (C. beticola).

The beets harvest occurred at 52 DAT. Five randomly chosen plants were collected from the 2 central planting lines of each experimental plot. Plant height $(\mathrm{mm})$, fresh and dry leaf weight $\left(\mathrm{g} \mathrm{plant}^{-1}\right)$ and diameter $(\mathrm{mm})$, length $(\mathrm{mm})$, fresh and dry weight $\left(\mathrm{g} \mathrm{plant}^{-1}\right)$ of roots were evaluated. The average yield was extrapolated to tones per hectare $\left(\mathrm{t} \mathrm{ha}^{-1}\right)$. All the results were subjected to the analysis of variance $(F$ test $)(\mathrm{p}<0.05)$ and the regression analyses $\left(\mathrm{p}<0.05, \mathrm{R}^{2}>0.70\right)$ using Sisvar 5.3 statistical software (Ferreira, 2011).

\section{Results and Discussion}

Plant height $(32.41 \mathrm{~cm})$ and the dry weight per plant of the leaf $(5.81 \mathrm{~g})$ and root $(27.62 \mathrm{~g})$ were not affected by vermiculite doses. For fresh leaf weight, a significant linear regression was detected, indicating the higher the vermiculite doses, the lower the fresh weights. This response can be observed in Figure 1 and indicates a reduction of 2.6571 grams of fresh leaf weight for each tone of vermiculite applied per hectare.

Figure 1. Fresh leaf weight $\left(\mathrm{g} \mathrm{plant}^{-1}\right)$ of beet in response to vermiculite doses $\left(\mathrm{t} \mathrm{ha}^{-1}\right)$.

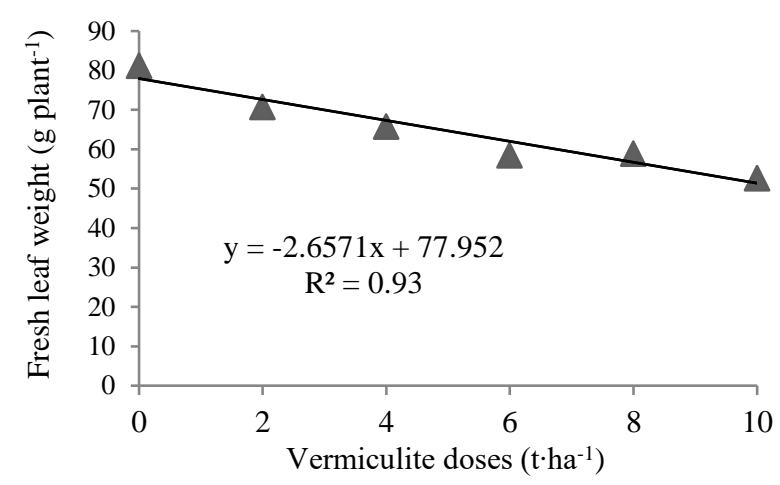

Source: Authors.

Throughout this study, the high precipitation level $(276.08 \mathrm{~mm})$ and average daily maximum and minimum temperatures were 28.2 and $16.7{ }^{\circ} \mathrm{C}$, respectively. The average air relative humidity was $75 \%$. Vermiculite can improve soil water retention (Vidigal et al., 2007), and this favors the development of cercosporiosis (C. beticola) because a low incidence of this disease was observed where no vermiculite was added $\left(\mathrm{t} \mathrm{ha}^{-1}\right)$. 
Cercosporiosis is also favored by high temperatures and prolonged periods of high air humidity and leaf wetting (Whitney and Duffus, 1986). A high number of leaf lesions, together with the accumulation of phytotoxins, induce leaf senescence, and the reduction in fresh weight (Weiland and Koch, 2004). Despite the incidence of C. beticola and the reductions in fresh weight with the addition of vermiculite, values were slightly higher than those reported by Silva et al. (2016) and Magro (2015), but lower than the indicated by Corrêa et al. (2014) and Candian et al. (2016).

The root length data adjusted to a quadratic model with a maximum length estimated at $2.62 \mathrm{t} \cdot \mathrm{ha} \mathrm{H}^{-1}$ of vermiculite as it is presented in Figure 2.

Figure 2. Beet root length $(\mathrm{mm})$ in response to vermiculite doses $\left(\mathrm{t} \mathrm{ha}^{-1}\right)$.

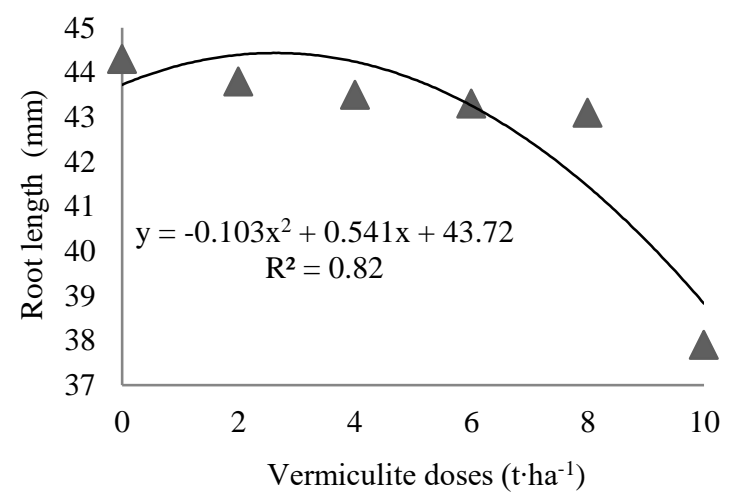

Source: Authors.

Although quadratic, the values obtained were similar to each other from the 0 to $4 \mathrm{t}^{\mathrm{h}} \mathrm{ha}^{-1}$ of vermiculite then decreased until $10 \mathrm{t}^{-\mathrm{ha}^{-1}}$. The beetroot diameter also adjusted to a quadratic model (Figure 3), with a diameter increase of up to $4.59 \mathrm{t} \cdot \mathrm{ha}^{-1}$ of vermiculite and a pronounced decrease until $10 \mathrm{t} \cdot \mathrm{ha}^{-1}$. Due to the incidence of $C$. beticola, values were lower than those reported by Corrêa et al. (2014), Magro et al. (2015), Candian et al. (2016), and Silva et al. (2016). However, the root diameter of the beetroots can be classified as of good quality, according to Tivelli et al. (2011).

Figure 3. Beet root diameter $(\mathrm{mm})$ in response to vermiculite doses $\left(\mathrm{t} \mathrm{ha}^{-1}\right)$.

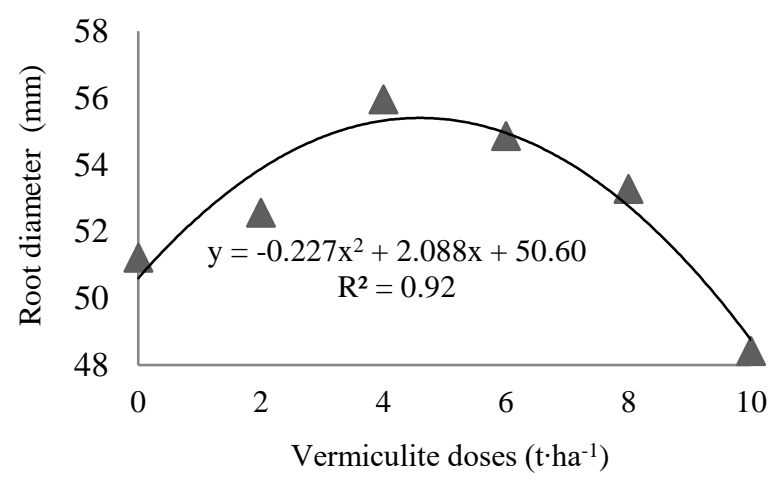

Source: Authors.

A linear reduction of the fresh root weight occurred with the increase of the vermiculite doses. This response can be observed in Figure 4 and indicates a reduction of 2.061 grams of fresh root weight for each tone of vermiculite applied per hectare. 
Figure 4. Fresh root weight $\left(\mathrm{g} \mathrm{plant}^{-1}\right)$ of beet in response to vermiculite doses $\left(\mathrm{t} \mathrm{ha} \mathrm{a}^{-1}\right)$.

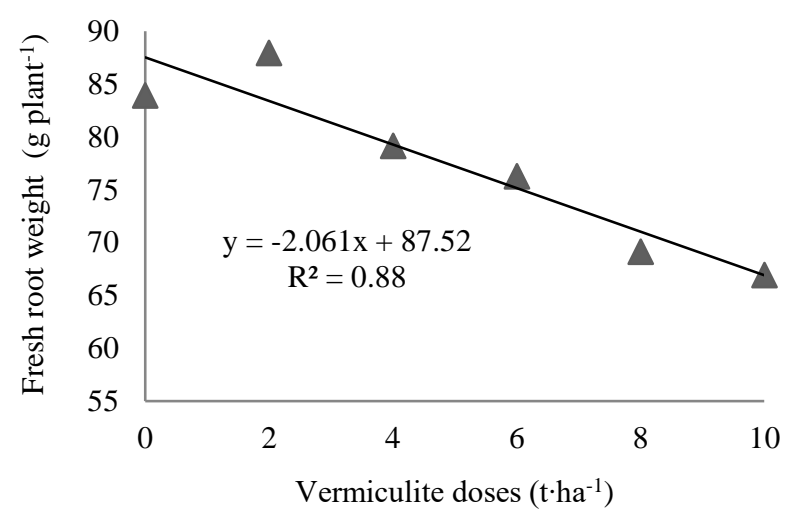

Source: Authors.

The values observed were lower than reported by Corrêa et al. (2014), Magro et al. (2015), Candian et al. (2016), and Silva et al. (2016), this was probably due to the excessive rainfall that favored the occurrence and establishment of cercosporiosis and use of an open-pollinated cultivar, while those authors studied hybrids that generally present superior productive potential. For beet yield $\left(\mathrm{t} \mathrm{ha}^{-1}\right)$, the same tendency occurred where a significant reduction was observed due to the increasing levels of vermiculite (Figure 5). Figure 5 indicates a reduction of 0.7479 ton ha $^{-1}$ of beet production for each tone of vermiculite applied per hectare.

Figure 5. Beet yield $\left(\mathrm{tha}^{-1}\right)$ in response to vermiculite doses $\left(t \mathrm{th}^{-1}\right)$.

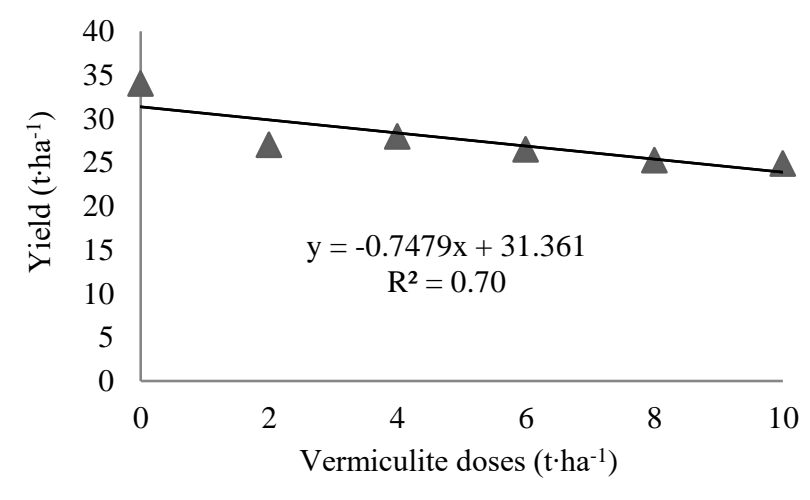

Source: Authors.

The excess of soil moisture caused by rainfall, combined with vermiculite doses caused saturation of the system, increases the incidence of cercosporiosis. Plants attacked by $C$. beticola have decreased photosynthetic capacity and high use of reserves to repair leaf damage, increasing yield losses (Pittner et al., 2007). Beet plants are more sensitive to waterlogging in the third stage of growth (from complete hypocotyl formation to harvest) compared to the first and second stages of development (Costa et al., 2008).

Soil saturation also affects root respiration due to the decrease in soil airflow (Kerbauy, 2012). Coil aeration and porosity can be improved if vermiculite is associated with organic compounds (Caldeira et al., 2013). However, the use of vermiculite did not appear to provide an overall benefit to beet production. 


\section{Conclusions}

The increase of vermiculite doses caused the linear decrease of the beet fresh root and leaf weight. Beet root length and diameter increased up to 2.62 and $4.59 \mathrm{t}^{\cdot \mathrm{ha}^{-1}}$ of vermiculite, respectively. The beet yield reductions observed were likely due to the high water holding capacity of vermiculite and to the consequent cercosporiosis incidence;

The use of vermiculite solely in beet production did not seem to provide benefits for the cultivation of this crop. Future research should focus on lower ranges of vermiculite doses $\left(<2.62 \mathrm{t} \mathrm{ha}^{-1}\right)$, and mixtures of vermiculite with other materials as a component for plant crop substrates, such as coconut husk fiber, crushed oyster shell, and sugar cane filter cake.

\section{Acknowledgments}

Coordination for the Improvement of Higher Education Personnel and National Council (CAPES).

\section{References}

Araújo, A. V., Silva, M. A. D., \& Ferraz, A. P. F. (2020). Germination and vigor of Encholirium spectabile seeds according to geographical region, substrate and sowing position. Research, Society and Development, 9(8), e865986245, 2020. 10.33448/rsd-v9i8.6245

Caldeira, M. V., Delarmelina, W. M., Peroni, L., Gonçalves, E. O., \& Silva, A. G. (2013). Use of sewage sludge and vermiculite for producing Eucalyptus seedlings. Pesquisa Agropecuária Tropical, 43(2), 155-163. 10.1590/S1983-40632013000200002

Candian, J. S., Spadoni, T. B., Cardoso, A. I. I., Watanabe, C. Y., \& Pinto, L. A. T. C. (2016). Influência do sulfato de magnésio na cultura da beterraba (Influence of magnesium sulphate on the beet crop). Revista de Biologia e Ciências da Terra, 16(2), 58-65.

Castro, G., Díaz, A., Sarquís, P., \& Elizondo, A. (2011) Aplicación de procesos físicos para la depuración de mineral de vermiculita de un yacimiento de Argentina (Application of physical processes for the purification of vermiculite ore from a deposit in Argentina). Revista Facultad de Ingeniería, 26, 1-10.

Chui, Q. S. H. (2005). Uso de vermiculita massapé paulistana como adsorvedora de metais (Using massapé paulistana vermiculite to adsorb elements of metals). Engenharia Sanitária e Ambiental, 10(1), 58-63. 10.1590/S1413-41522005000100007

Corrêa, C. V., Cardoso, A. I. I., Souza, L. G., Antunes, W. L. P., \& Magolbo, L. A. (2014). Yield of beet depending on spacing. Horticultura Brassileira, 32(1), 111-114. 10.1590/S0102-05362014000100019

Costa, R. N. T., Vasconcelos, J. P., Silva, L. A., \& Ness, R. L. L. (2008). Effect of excess of water on sugarbeet yield components. Horticultura Brassileira, 26(1), 74-77. 10.1590/S0102-05362008000100014

Cunha, A. R., \& Martins, D. (2009). Climatic classification for the districts of Botucatu and São Manuel, SP. Irriga, 14(1), 1-11. 10.15809/irriga.2009v14n1p01

Curbelo, F.D.S. (2002). Estudo da remoção de óleo em águas produzidas na indústria de petróleo, por adsorção em coluna utilizando a vermiculita expandida $e$ hidrofobizada (Study of oil removal in water produced in oil industry, by adsorption in coluna using expanded and hydrophobicized vermiculite). Tesis de Maestria. Universidade Federal do Rio Grande do Norte, Natal, RN, Brasil.

Ferraz, G. X. L., Silva, M. A. D., Alves, R. M., Freire, E., Alves, R. J. R., \& Ferraz, E. X. L. (2020). Germination of Amburana cearensis (Allemao) A. C. Sm. submitted to different substrates. Research, Society and Development, 9(10), p. e7009109005, 10.33448/rsd-v9i10.9005

Ferreira, D.F. (2011). Sisvar: A computer statistical analysis system. Ciência e Agrotecnologia, 35(6), 1039-1042. 10.1590/S1413-70542011000600001

Figliolia, M. B., Oliveira, E. C., \& Piña-Rodrigues, F. C. M. (1993). Análise de sementes (Seed analysis) (pp. 137-174). In: Aguiar, I. B., Piña-Rodrigues, F. C. M., \& Figliolia, M. B. (eds.). Sementes florestais tropicais (Tropical tree seeds). Abrates, Brasília, Brasil.

Filgueira, F. A. R. (2012). Novo manual de olericultura: Agrotecnologia moderna na produção e comercialização de hortaliças (New manual of horticulture: Modern agro-technology in the production and commercialization of vegetables). 3rd ed. Viçosa, Brazil.

França, S. C. A., Arruda, G. M., \& Ugarte, J. F. O. (2006). Desenvolvimento tecnológico para as vermiculitas brasileiras (Technological development for Brazilian vermiculites). Relatório Técnico, Centro de Tecnlogia Mineral, Belém, Brazil.

Gooch, J. W. (2011). Encyclopedic dictionary of polymers. (2nd ed.), Springer.

Kerbauy, G. B. (2012). Fisiologia vegetal (Plant Physiology). (2nd ed.), Guanabara Koogan.

Magro, F. O., Silva, E. G., Takata, W. H. S., Cardoso, A. I. I., Fernandes, D. M., \& Evangelista, R. M. (2015). Organic compost and potassium top dressing fertilization on production and quality of beetroot. Australian Journal of Crop Science, 9(10), 962-967.

Oliveira, L. C., Costa, E., Cortelassi, J. A. S., \& Rodrigues, E. T. (2012). Formation of beetroot seedlings in different protected environments, substrates and containers in Aquidauana region, State of Mato Grosso do Sul, Brazil. Engenharia Agrícola, 32(3), 415-422. 10.1590/S0100-69162012000300001

Orellana, R. B. G. (2016). Evaluación del uso de vermiculita y perlita como alternativas al Phytagel® en la propagación in vitro de camote (Ipomoea batatas L.). Tesis de licenciatura. Escuela Agrícola Panamericana, Zamorano Honduras. 
Pereira, A. S., Shitsuka, D. M., Parreira, F. J., \& Shitsuka, R. (2018). Metodologia da pesquisa científica.. Ed. UAB / NTE / UFSM. https://repositorio. ufsm. br/bitstream/handle/1/15824/Lic_Computacao_Metodologia-Pesquisa-Cientifica.pdf

Pittner, E., Piva, R., Santos, J. C., Santos, L. A., \& Duarte, R. F. (2016). Analysis of the development of Cercospora beticola forward to a systemic fungicidal. Applied Research \& Agrotechnology, 9(3), 53-60. 10.5935/PAeT.V9.N3.06

Raij, B. V., Cantarella, H., Quaggio, J. A., \& Furlani, A. M. C. (1997). Recomendações de adubação e calagem para o Estado de São Paulo (Fertilization and liming recommendations for the State of São Paulo). (2nd ed.), Campinas, Instituto Agronômico de Campinas, Campinas, Brazil.

Sediyama, M. A. N., Santos, M. R., Vidigal, S. M., \& Salgado, L. T. (2011). Yield and nutrient export of sugar beet under mulching and organic fertilization. Revista Brasileira de Engenharia Agrícola e Ambiental, 15(9), 883-889. 10.1590/S1415-43662011000900002

Silva, P. N. L., Lanna, N. B. L., \& Cardoso, A. I. I. (2016). Beet production depending on rates of castor bean cake as topdressing. Horticultura Brasileira, 34(3), 416-421. 10.1590/S0102-05362016003018

Silva, R. A. O., Silva, M. C. C., Sousa, H. R., Silva, M. G. O., Santos, M. R., \& Brandim, A. S. (2015). Technological prospecting of the use of vermiculite clay as adsorbent of oily contaminants in biodiesel production process. Cadernos de Prospecção, 8(3), 544-551. 10.9771/S.CPROSP.2015.008.060

Tivelli, S. W., Factor, T. L., Teramoto, J. R. S., Fabri, E. G., Moraes, A. R. A., Trani, P. E., \& May, A. (2011). Beterraba: do plantio à comercialização. Boletim Técnico n. 210, IAC - Campinas.

Ugarte, J. F. O., Sampaio, J. A., \& França, S. C. A. (2005). Vermiculita (Vermiculite). In: Luz, A. and L. F. Freitas (eds.). Rochas \& minerais industriais usos e especificações (pp. 677-698). Centro de Tecnologia Mineral, Brasil.

Vidigal, D. D. S., Brasileiro, B. G., Dias, D. C. F. S., Alvarenga, E. M., \& Bhering, M. C. (2007). Germination and post-seminal development of Neem (Azadirachta indica A. Juss. - Meliaceae) seeds. Revista Brasileira de Sementes, 29(3), 39-46. 10.1590/S0101-31222007000300005

Villegas, T. O. G., Dominguez, P. M. L., Albaver, P. M., Rodriguez, M. A., Sotelo, N. H., Martinez, R. M. G., Aguilar, C. M., Castillo, C. C., \& Magadan, S. M. C. (2017). Substratos como material de última generación (Substrates as latest generation material). Omnia Publisher SL., Barcelona, Spain.

Weiland, J., \& Koch, G. (2004). Sugarbeet leaf spot disease (Cercospora beticola Sacc.). Molecular Plant Pathology, 5(3), 157-166. 10.1111/j.13643703.2004.00218.x

Whitney, E. D., \& Duffus, J. E. (1986). Compendium of beet diseases and insects. American Phytopathological Society, St. Paul, MN.

Xavier, F. A. S., Maia, S. M. F., Ribeiro, K. A., \& Mendonça, E. S. (2013). Effect of cover plants on soil C and N dynamics in different soil management systems in dwarf cashew culture. Agriculture, Ecosystems \& Environment, 165(1), 173-183. 10.1016/j.agee.2012.12.003 